\title{
I.UMIBUNG
}

\section{RANCANG BANGUN DAN ANALISA ALAT PENCUCI WORTEL TIPE DRUM}

\section{Muhammad Adam ${ }^{1}$, Sardino, Dio Winaldi, Suryadi Candra, Febri Yulsa Yunika, Riko, Sri Aulia Novita, Fithra Herdian, Hendra, Indra Laksmana}

${ }^{1)}$ Program Studi Teknologi Mekanisasi Pertanian, Politeknik Pertanian Negeri Payakumbuh Korespondensi: m.adam191297@gmail.com

\author{
Diterima : 14 Januari 2020 \\ Disetujui : 28 Februari 2020 \\ Diterbitkan : 29 Februari 2020
}

\begin{abstract}
ABSTRAK
Alat pencuci wortel dibuat untuk membantu meningkatkan kualitas hasil panen tanaman wortel. Hasil uji kinerja alat pencuci wortel tipe drum diperoleh kapasitas efektif alat sebesar $210 \mathrm{~kg} / \mathrm{jam}$. Hasil perhitungan analisa ekonomi didapat biaya tetap sebesar Rp.1.059.300/tahun, biaya tidak tetap Rp.16.644/jam, biaya pokok Rp.81/kg dan break event point (BEP) untuk pengoperasian alat ini adalah $3.302 \mathrm{~kg} / \mathrm{tahun}$.
\end{abstract}

Keywords: wortel, pencuci, drum

\begin{abstract}
Carrot washing tool is made to help improve the quality of carrot crop yields. The performance test of the carrot washing tool type drum was found to have an effective capacity of $210 \mathrm{~kg} / \mathrm{hour}$. The results of the economic analysis show the fixed cost of Rp. 1,059,300 / year, the variable cost of Rp. 16,644 / hour, the basic cost of Rp. $81 / \mathrm{kg}$ and the break event point (BEP) for the operation of this tool is 3,302 $\mathrm{kg} /$ year.
\end{abstract}

Keywords: carrots, washers, drums

\section{PENDAHULUAN}

Wortel (Daucus carota L.) merupakan tumbuhan jenis sayuran umbi berwarna kuning kemerahan atau jingga kekuningan dengan tekstur serupa kayu (Malasari 2005). Wortel adalah sumber vitamin A karena memiliki kandungan karoten yang tinggi. Karoten di dalam tubuh akan diubah menjadi vitamin A, zat gizi yang sangat penting untuk fungsi retina (Khomsan, 2007). Selain itu kandungan karoten juga membuat umbi wortel berwarna kuning kemerahan (Malasari, 2005). Wortel juga merupakan sayuran yang multi khasiat bagi 


\section{I.UMIBUNG}

pelayanan kesehatan masyarakat luas. Di Indonesia, wortel dianjurkan sebagai bahan pangan potensial untuk mengatasi masalah kekurangan vitamin A, mencegah penyakit rabun senja (buta ayam) dan masalah kurang gizi.

Pencucian adalah kegiatan pasca panen wortel yang bertujuan untuk menghilangkan kotoran, tanah dan debu, mempertahankan kesegaran, mempercantik tampilan, serta meningkatkan harga jual (Utama, 2001). Pencucian dapat meningkatkan kebersihan umbi wortel, sehingga dapat mengurangi bahkan meniadakan jasad-jasad renik yang menempel pada umbi dengan demikian umbi lebih aman dari serangan patogen selama penyimpanan hingga sampai ke konsumen. Pencucian juga berfungsi untuk menurunkan suhu umbi sehingga dapat memperpanjang kesegaran umbi. Selain itu, pencucian juga membuat penampilan umbi wortel lebih menarik, sehingga meningkatkan daya tarik konsumen (Manalu, 2007).

Berdasarkan hasil pengamatan atau survei lokasi di Bukittinggi, para petani melakukan pencucian wortel di selokan-selokan dengan cara menyikat wortel satu per satu. Kegiatan pencucian wortel dengan cara ini kurang efektif dan efisien baik dari segi waktu dan tenaga. Untuk itu dibuat alat pencuci wortel tipe drum yang mampu membersihkan wortel lebih banyak dan cepat dengan hasil yang bersih tanpa merusak kualitas wortel.

\section{METODE PENELITIAN}

\section{Alat dan Bahan}

Alat - alat yang akan digunakan dalam pembuatan alat pencuci wortel tipe drum dapat dilihat pada Tabel 1 . 


\section{I.UMIBUNG}

Tabel 1. Alat-alat yang digunakan

\begin{tabular}{cllc}
\hline No & \multicolumn{1}{c}{ Jenis Alat } & \multicolumn{1}{c}{ Spesifikasi } & Jumlah \\
\hline 1 & Mesin las listrik & BX6-250 & 1 unit \\
2 & Mesin gerinda tangan & Makita A24SBF & 1 unit \\
3 & Mesin gerinda potong & Makita 2414NB & 1 unit \\
4 & Mesin bor & Bosch (Gm B 320) & 1 unit \\
5 & Rol siku & Stainless stell & 1 buah \\
6 & Sikat kawat & Owner & 1 buah \\
7 & Palu & S GS 600 g & 1 buah \\
8 & Meteran & Essen 5 m & 1 buah \\
9 & Pemaku keling & 1,18 mm & 1 buah \\
10 & Ragum & Jonnesway & 1 buah \\
11 & Gunting seng & Tekiro & 1 buah \\
\hline
\end{tabular}

Bahan-bahan yang akan digunakan dalam pembuatan alat pencuci wortel tipe drum dapat dilihat pada Tabel 2.

Tabel 2. Bahan-bahan yang digunakan

\begin{tabular}{lll}
\hline No & \multicolumn{1}{c}{ Jenis Bahan } & Spesifikasi \\
\hline 1. & Besi strip $20 \mathrm{~mm} \times 2 \mathrm{~mm} \times 600 \mathrm{~mm}$ & $1 / 2$ batang \\
2. & Besi siku $40 \mathrm{~mm} \times 3 \mathrm{~mm} \times 600 \mathrm{~mm}$ & $1 \frac{1}{2}$ batang \\
3. & Elektroda 2.6 & 1 kilogram \\
4. & Besi poros 1 inchi & 1 meter \\
5. & Bearing UCP & 2 buah \\
6. & Bearing temple & 2 buah \\
7. & V-belt & 2 buah \\
\hline
\end{tabular}




\section{I.UMIBUNG}

\begin{tabular}{|c|c|c|}
\hline 8. & -Puli 4 inchi & 1 buah \\
\hline & -Puli 3 inchi & 2 buah \\
\hline & -Puli 2,5 inchi & 1 buah \\
\hline 9. & Motor listrik $1 \mathrm{hp}$ & 1 unit \\
\hline 10. & Speed reducer & 1 unit \\
\hline 11. & Drum pastik sedang & 1 buah \\
\hline 12. & Poros kayu & 1 buah \\
\hline 13. & Nilon & 2 gulung \\
\hline 14. & Sikat bros & 1 buah \\
\hline 15. & Lem silicon & 1 buah \\
\hline 16. & Lem plastic & 4 buah \\
\hline 17. & Cat duko & 1 kaleng \\
\hline 18. & Kuas & 1 buah \\
\hline 19. & Engsel pintu ukuran kecil & 2 buah \\
\hline 20. & Pengunci pintu & 2 buah \\
\hline 21. & Poros sikat kayu D 30mm x $130 \mathrm{~mm}$ & 7 buah \\
\hline 22. & Kawat ayakan & $1 / 2$ meter \\
\hline 23. & Paku keling & 20 buah \\
\hline 24. & Baut $10 \mathrm{~mm}$ & 6 buah \\
\hline 25. & Baut $14 \mathrm{~mm}$ & 8 buah \\
\hline
\end{tabular}

\section{Bagan Alir Pembuatan Alat Pencuci Wortel Tipe Drum}

Langkah-langkah pembuatan alat pencuci wortel tipe drum dapat dilihat pada Gambar 1. 


\section{I.UMIBUNG}

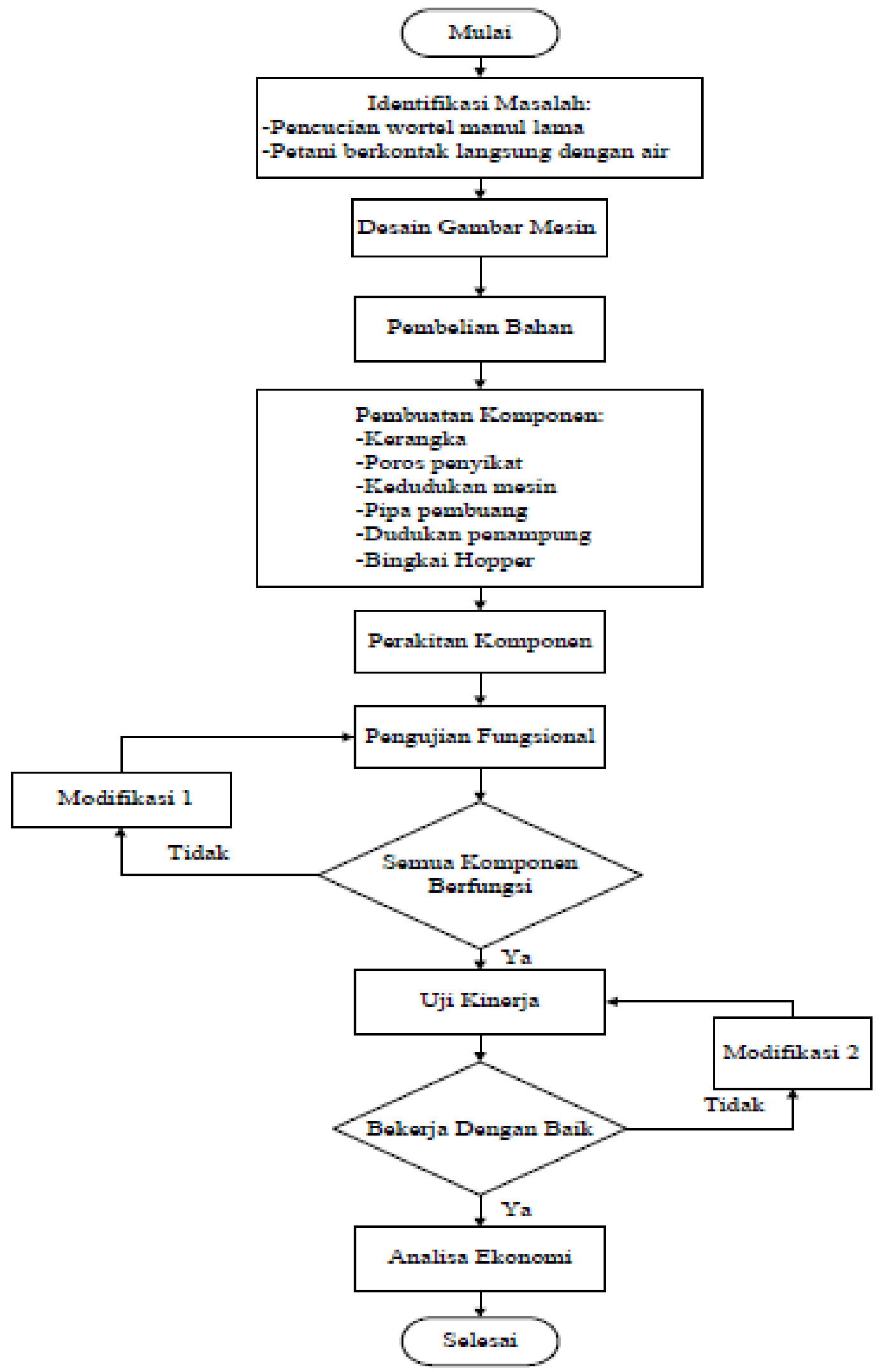

Gambar 1. Bagan alir pembuatan alat pencuci wortel tipe drum 


\section{I.UMIBUNG}

\section{Rancangan Alat}

Rancangan fungsional dan struktural menjelaskan tentang fungsi dan dimensi atau ukuran dari setiap komponen alat pencuci wortel tipe drum. Dalam perancangan alat, ada beberapa hal yang harus dilakukan secara terstruktur untuk menghindari kesalahan dalam pembuatan yang dapat mengurangi kinerja alat. Rancangan struktural dan fungsional alat pencuci wortel tipe drum terdiri dari:

Kerangka

Kerangka berfungsi sebagai penyangga atau penopang semua komponen alat pencuci wortel tipe drum. Kerangka terbuat dari besi siku berukuran panjang $78 \mathrm{~cm}$, lebar $70 \mathrm{~cm}$ dan tinggi $50 \mathrm{~cm}$. Kerangka dapat dilihat pada Gambar 2.

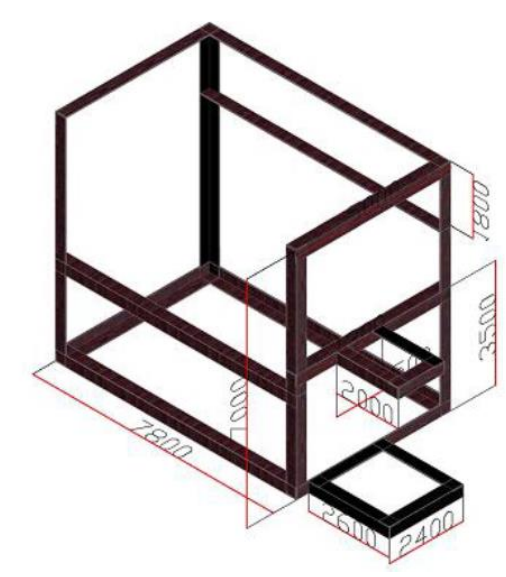

Gambar 2. Kerangka

Drum plastik

Drum plastik berfungsi sebagai wadah atau tempat pencucian, hopper dan juga sebagai outlet. Drum plastik memiliki panjang $60 \mathrm{~cm}$ dengan diameter $40 \mathrm{~cm}$. Drum plastik dapat dilihat pada Gambar 3. 


\section{I.UMIBUNG}

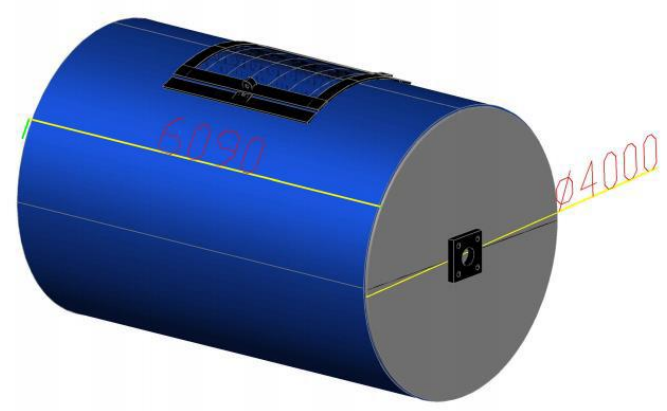

Gambar 3. Drum plastik

Motor listrik

Motor listrik merupakan sumber tenaga penggerak dari alat pencuci wortel tipe drum. Motor listrik dapat dilihat pada Gambar 4.

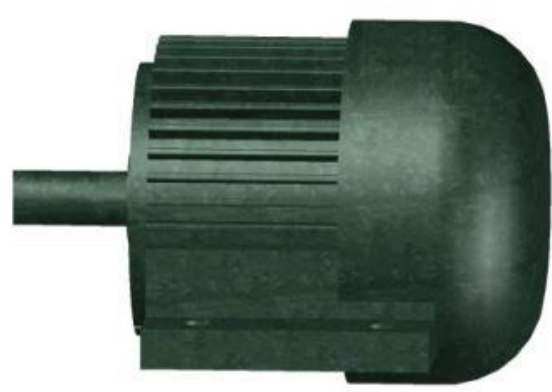

Gambar 4. Motor listrik

Puli dan sabuk V

Puli dan sabuk V berfungsi sebagai sistem transmisi untuk meneruskan putaran yang dihasilkan oleh motor listrik ke poros penyikat untuk membersihkan wortel. Puli yang digunakan berdiameter 2.5, 3 dan 4 inchi Sabuk yang digunakan berukuran B-30 dan B-32. Puli dan sabuk dapat dilihat pada Gambar 5.

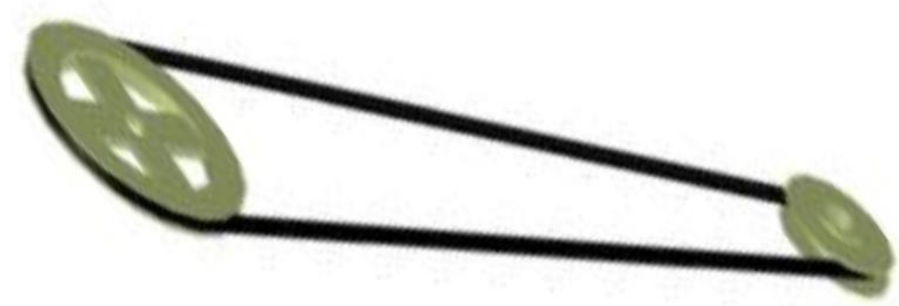

Gambar 5. Puli dan sabuk V 


\section{I.UMIBUNG}

Poros sikat pencuci

Poros sikat ini berfungsi sebagai penyikat wortel dalam proses pencucian wortel. Poros berdiameter $8 \mathrm{~cm}$ dan panjang $56 \mathrm{~cm}$. Penyikat berdiameter $3 \mathrm{~cm}$ dan panjang $13 \mathrm{~cm}$ yang berjumlah 7 buah. Poros sikat pencuci dapat dilihat pada Gambar 6 .

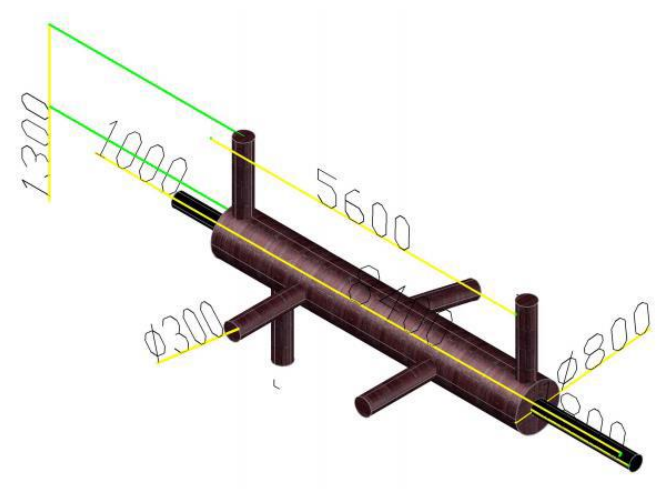

Gambar 6. Poros sikat pencuci

\section{Hopper}

Hopper berfungsi untuk menutup drum agar sewaktu pencucian wortel tidak keluar. Hopper memiliki ukuran panjang $25 \mathrm{~cm}$ dan lebar $17 \mathrm{~cm}$. Hopper dapat dilihat pada Gambar 7.

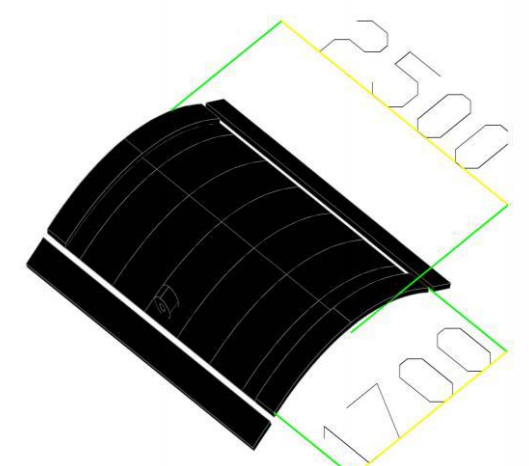

\section{Gambar 7 . Hoper}

\section{Bantalan}

Jenis bantalan yang digunakan pada alat pencuci wortel tipe drum adalah bantalan UCP 205. Bantalan UCP dapat dilihat pada Gambar 8. 


\section{I.UMIBUNG}

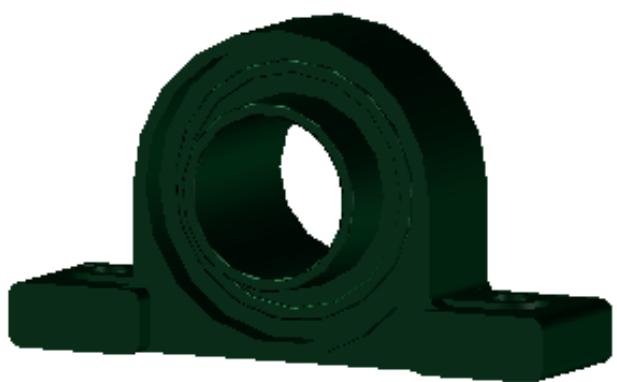

Gambar 8. Bantalan

Speed reducer

Speed reducer merupakan suatu perangkat yang dapat menambah kekuatan beban/torsi dengan cara merubah kecepatan dari dinamo motor.

Kran

Kran berfungsi untuk mengeluarkan air bekas cucian ketika proses pencucian telah selesai.

\section{HASIL DAN PEMBAHASAN}

Hasil dari perakitan alat pencuci wortel tipe drum dapat dilihat pada Gambar 10.

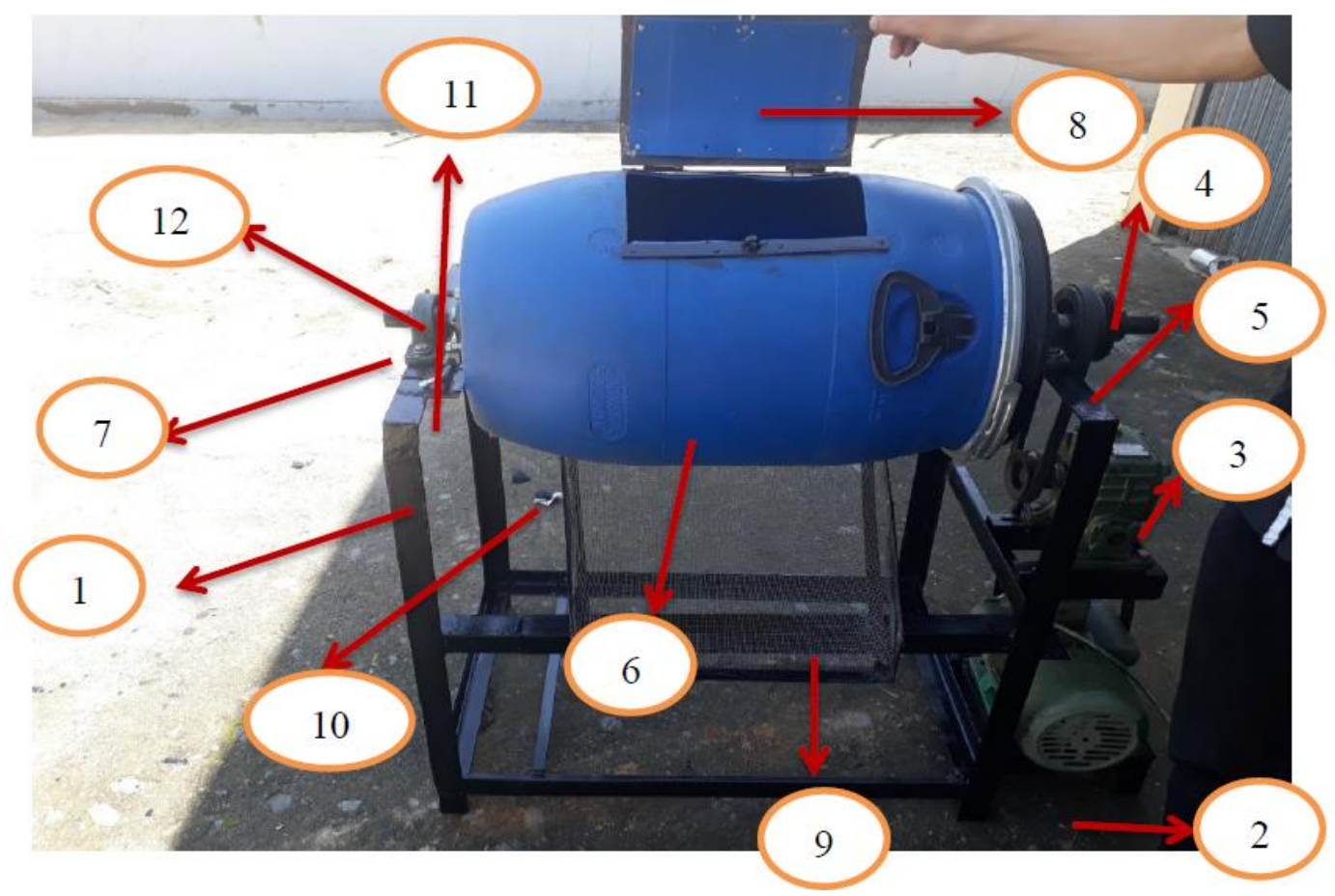

Gambar 10. Alat pencuci wortel tipe drum 
Vol. 19 No. 1 Februari 2020

ISSN 1412-1948

\section{I.UMIBUNG}

Keterangan gambar:

1. Rangka utama

2. Motor listrik

3. Speed reducer

4. Puli

5.Sabuk V

6. Drum pencuci

7. Drum pencuci

8. Hopper/Output

9. Tempat penampungan

10. Pipa pembuang air

11. Pengunci drum

12. Bantalan 


\section{I.UMIBUNC}

Cara kerja alat pencuci wortel tipe drum yaitu putaran motor listrik akan memutar puli dan puli motor listrik dihubungkan ke puli input speed reducer dan putaran akan diteruskan ke puli output speed reducer dan diteruskan ke puli poros yang terhubung dengan sikat pencuci. Putaran sikat pencuci akan membuat wortel saling bergesekan dengan sikat pencuci sehingga kotoran akan lepas, dan kotoran akan didorong oleh air keluar melalui lubang pengeluaran, sehingga wortel akan bersih.

\section{Uji Kinerja}

Dari hasil pengujian yang dilakukan pada $10 \mathrm{~kg}$ wortel maka di peroleh hasil yang dapat dilihat pada Tabel 3 .

Tabel 3. Hasil uji kinerja

\begin{tabular}{lllll}
\hline No & \multicolumn{1}{c}{ Uraian } & Uji 1 & Uji 2 & Rata-rata \\
\hline 1 & Berat total wortel (kg) & 5 & 5 & 5 \\
2 & Berat total wortel yang telah dicuci $(\mathrm{kg})$ & 4.7 & 4.9 & 4.8 \\
3 & Waktu pencuciam (jam) & 0.023 & 0.023 & 0.023 \\
4 & Kapasitas (Kg/jam) & 208 & 213 & 210.5 \\
5 & Air mengalir & Y & Y & \\
6 & Banyak air (Liter) & 28 & 28 & 28 \\
\hline
\end{tabular}

Dari hasil pengujian yang telah dilakukan, pada tahap pertama dan kedua wortel seberat $5 \mathrm{~kg}$ dicuci dengan waktu 0,023 jam dengan air mengalir (Y) dengan berat bersih wortel setelah pencucian menjadi 4.7 dan $4.9 \mathrm{~kg}$. Hasil uji kinerja RPM puli alat pencuci wortel tipe drum dapat dilihat pada Tabel 4. 


\section{I.UMIBUNG}

Tabel 4. Hasil uji kinerja RPM puli

\begin{tabular}{|c|c|c|c|c|c|}
\hline \multirow{4}{*}{$\begin{array}{l}\mathrm{N} \\
\mathrm{o}\end{array}$} & \multirow{4}{*}{ Perlakuan } & \multicolumn{4}{|c|}{ RPM Puli } \\
\hline & & \multirow{3}{*}{ RPM motor } & RPM & RPM & \multirow{3}{*}{ RPM poros } \\
\hline & & & & & \\
\hline & & & speed reducer (in) & speed reducer (in) & \\
\hline 1 & Tanpa beban & 1.425 & 1.386 & 46,2 & 35.25 \\
\hline 2 & Beban 4 kg & 1.422 & 1.377 & 46,1 & 34,93 \\
\hline \multirow[t]{2}{*}{3} & Beban $5 \mathrm{~kg}$ wortel & 1.418 & 1.375 & 45,9 & 33.60 \\
\hline & Rata-rata & $1.421,6$ & 1.379 & 46,06 & 34,59 \\
\hline
\end{tabular}

Dari Tabel 4 dapat disimpulkan bahwa penguji tanpa beban RPM motornya adalah 1,425 dan direduksi dengan speed reducer dan menghasilkan RPM pada poros pencuci sebesar 35,25 dan pengujian beban $5 \mathrm{~kg}$ RPM motor 1,418 dan RPM poros pencuci 33,60. Kapasitas alat

Kapasitas alat pencuci wortel diperoleh dengan rumus (Irwan A. \& Novita, 2016): $\mathrm{C}=\frac{\mathrm{W}}{\mathrm{t}}=\frac{5 \mathrm{~kg}}{0.023 \mathrm{jam}}=217,4 \mathrm{~kg} / \mathrm{jam}$

Keterangan :

$\mathrm{C}=$ Kapasitas alat pencuci wortel $(\mathrm{kg} / \mathrm{jam})$

$\mathrm{W}=$ Bobot bahan cucian yang di tampung dari lubang keluaran selama waktu tertentu $(\mathrm{kg})$

$\mathrm{t}=$ Waktu yang ditentukan untuk menampung keluaran wortel yang telah dicuci melalui lubang keluaran (jam)

Persentase kerusakan

Persentase kerusakan adalah kerusakan yang didapatkan dari hasil pencucian wortel. Persentase kerusakan dihitung dengan rumus sebagai berikut, (Irwan A. \& Novita, 2016) 


\section{I.UMIBUNG}

$\% \mathrm{br}=\frac{\mathrm{Wbr}}{\mathrm{Ws}} \times 100=\frac{200 \mathrm{gr}}{10.000 \mathrm{gr}} \times 100=2 \%$

Keterangan :

$\%$ br $=$ Persentase rusak $(\%)$

Wbr $=$ Berat irisan yang rusak berdasarkan klasifikasi (gr)

Ws $=$ Berat sampel (gr)

\section{Analisa Ekonomi}

Asumsi yang digunakan pada biaya operasional mesin pencuci wortel tipe drum dihitung sebagai berikut:

$\begin{array}{ll}\text { Harga jual alat }(\mathrm{P}) & =\mathrm{Rp} .4 .035 .500 \\ \text { Umur ekonomis }(\mathrm{N}) & =4 \text { tahun } \\ \text { Harga akhir }(\mathrm{S}) & =10 \% \mathrm{x} \mathrm{P} \\ \text { Bunga akhir (i) } & =6 \% / \text { Tahun } \\ \text { Jam kerja / Tahun }(\mathrm{X}) & =2.400 \text { jam } / \text { tahun } \\ \text { Jam kerja / hari } & =8 \mathrm{jam} \\ \text { Upah operator } & =\mathrm{Rp} .80 .000 / \text { hari } \\ \text { Jumlah operator } & =1 \mathrm{orang} \\ \text { Upah/sewa alat } & =\mathrm{Rp} .400 / \mathrm{kg}\end{array}$

\section{Biaya tetap}

Biaya tetap merupakan biaya yang dikeluarkan walaupun alat dan mesin yang kita gunakan tidak dioperasikan, dimana biaya ini bersifat independen terhadap pemakaian alat dan mesin (Irwan A. \& Novita, 2016). Biaya tidak tetap alat pencuci wortel:

Biaya penyusutan (D)

$D=\frac{P-S}{N}=\frac{R p .4 .035 .500-R p .403 .550}{4 \text { tahun }}=$ Rp. 908.000/tahun 


\section{I.UMIBUNG}

Keterangan :

$\mathrm{D}=$ Biaya penyusutan $(\mathrm{Rp} / \mathrm{tahun})$

$\mathrm{P}=$ Harga jual $(\mathrm{Rp})$

$\mathrm{S}=$ Harga akhir $(\mathrm{Rp})(10 \% \times \mathrm{P})$

$\mathrm{N}=$ Perkiraan umur ekonomis (Tahun)

Bunga modal (I)

$\mathrm{I}=\frac{\mathrm{i}(\mathrm{P})(\mathrm{N}+1)}{2 \mathrm{~N}}=\frac{6 \%(R p .4 .035 .500)(4+1)}{2 \times 4 \text { tahun }}=$ Rp. 151.300/tahun

Keterangan :

$\mathrm{I}=$ Bunga modal (Rp/tahun)

$\mathrm{i}=$ Suku bunga bank (\%/tahun)

Biaya tetap $=$ Biaya penyusutan + Biaya bunga modal

$$
=\text { Rp. 908.000/tahun }+ \text { Rp. 151.300/tahun = Rp. 1.059.300/tahun }
$$

\section{Biaya tidak tetap}

Biaya tidak tetap merupakan biaya yang dikeluarkan tergantung sedikit atau banyaknya alat dan mesin yang akan dioperasikan dan biaya ini sangat dipengaruhi oleh jam kerja pemakaian alat, (Irwan A. \& Novita, 2016). Biaya tidak tetap untuk alat pencuci wortel tipe drum adalah:

Upah operator

Upah operator $=\frac{\text { Upah }(\mathrm{Rp} / \mathrm{hari}) \mathrm{x} \text { Jumlah operator }}{\text { Jam kerja } / \text { hari }}=\frac{\mathrm{Rp} .80 .000(\mathrm{Rp} / \mathrm{hari}) \mathrm{x} 1}{8 \mathrm{Jam} / \mathrm{hari}}=\mathrm{Rp} .10 .000 / \mathrm{jam}$ Biaya perawatan

Biaya perawatan $=\frac{1,2 \% \mathrm{x}(\mathrm{P}-\mathrm{S})}{100 \mathrm{jam}}=\frac{1,2 \% \mathrm{x}(\mathrm{Rp} .4 .035 .500-\mathrm{Rp} .403 .550)}{100 \mathrm{jam}}=\mathrm{Rp} .544 / \mathrm{jam}$

Biaya listrik

Biay listrik $=$ daya $\mathrm{x}$ harga listrik $/ \mathrm{kwh}=0.75 \mathrm{kw} \times \mathrm{Rp} .1 .467 / \mathrm{kwh}=\mathrm{Rp} .1 .100 / \mathrm{jam}$ 


\section{I.UMIBUNC}

Biaya air

Biaya air = pemakaian air $\mathrm{x}$ tarif air

$$
=1,16 \mathrm{~m}^{3} / \mathrm{jam} \times \mathrm{Rp} .4000=\mathrm{Rp} \cdot 4 \cdot 640 / \mathrm{jam}
$$

Biaya tidak tetap $=$ Upah operator + Biaya perawatan + Biaya listrik + Biaya air

$$
\begin{aligned}
& =\text { Rp. } 10.000 / \mathrm{jam}+\mathrm{Rp} \cdot 544 / \mathrm{jam}+\mathrm{Rp} 1.100 / \mathrm{jam}+\mathrm{Rp} \cdot 4 \cdot 640 / \mathrm{jam} \\
& =\text { Rp. } 16.284 / \mathrm{jam}
\end{aligned}
$$

\section{Biaya pokok}

Biaya pokok merupakan biaya yang diperlukan oleh suatu mesin untuk setiap unit produksi, (Irwan A. \& Novita, 2016). Rumus biaya pokok sebagai berikut :

$\mathrm{BP}=\frac{\frac{\mathrm{BT}}{\mathrm{X}}+\mathrm{BTT}}{\mathrm{C}}=\frac{\frac{\mathrm{Rp} \cdot 1.059 .300 / \mathrm{tahun}}{2400 \mathrm{jam} / \mathrm{tahun}}+\mathrm{Rp} \cdot 16.644 / \mathrm{jam}}{210 \mathrm{~kg} / \mathrm{jam}}=\mathrm{Rp} .81 / \mathrm{kg}$

Keterangan :

$\mathrm{BP}=$ Biaya pokok $(\mathrm{Rp} / \mathrm{Kg})$

$\mathrm{X}=$ Jumlah jam kerja (Jam/Tahun)

$\mathrm{C}=$ Kapasitas alat $(\mathrm{Kg} / \mathrm{Jam})$

\section{Break event point pengoperasian alat}

Break event point (BEP) merupakan keadaan alat atau mesin yang beroperasi (melakukan pencucian) dengan keadaan tidak merugikan dan tidak menguntungan (titik balik pulang pokok). Jumlah pendapatan sama besarnya dengan jumlah biaya, (Irwan A. \& Novita, 2016). Analisa ini mempelajari pengaruh timbal balik antara pendapatan, biaya dan keuntungan. Rumus BEP yaitu :

$$
\mathrm{BEP}=\frac{\mathrm{BT}}{\mathrm{R}-\left(\frac{\mathrm{BTT}}{\mathrm{C}}\right)}=\frac{R p \cdot 1.059 .300 / \text { tahun }}{\mathrm{Rp} .400 / \mathrm{kg}-\left(\frac{\mathrm{Rp} .16 .644 / \mathrm{jam}}{210 \mathrm{~kg} / \mathrm{jam}}\right)}=3.302 \mathrm{~kg} / \mathrm{tahun}
$$




\section{I.UMIBUNG}

Keterangan :

$\mathrm{BEP}=$ Break event point $(\mathrm{Kg} / \mathrm{tahun})$

$\mathrm{R}=\mathrm{Upah} /$ Sewa alat $(\mathrm{Rp} / \mathrm{Kg})$

Dengan hasil analisa di atas maka alat ini layak dipakai karena waktu pencuciannya lebih cepat dibandingkan dengan pencucian manual dan dari segi biaya lebih murah

\section{KESIMPULAN DAN SARAN}

Alat pencuci wortel tipe drum memiliki spesifikasi tinggi $50 \mathrm{~cm}$, lebar $70 \mathrm{~cm}$, dan dilengkapi dengan poros sudu-sudu yang berjumlah 7 dengan panjang setiap sudusudu $13 \mathrm{~cm}$ dan diameter $8 \mathrm{~cm}$. Dari pengujian yang telah dilakukan maka didapat kapasitas efektif alat pencuci wortel ini adalah $210 \mathrm{~kg}$ wortel/jam dan persentase kerusakan $2 \%$ dari berat $5 \mathrm{~kg}$ wortel dengan membutuhkan waktu pencucian $0,023 \mathrm{jam}$. Hasil perhitungan analisa ekonomi didapat total biaya tetap Rp.1.059.300/tahun, total biaya tidak tetap Rp.16.644/jam, sedangkan biaya pokok alat pencuci wortel tipe drum ini adalah Rp.81/kg dan BEP untuk pengoperasian alat ini adalah $3.302 \mathrm{~kg} / \mathrm{tahun}$. Alat ini masih perlu dimodifikasi terutama pada poros sikat agar kapasitas pencucian wortel bisa dimaksimalkan. Putaran pada poros perlu direduksi lagi supaya wortel tidak gores atau rusak. Kran pengeluaran air perlu diperbesar supaya kotoran dan lumpur lebih cepat keluar.

\section{REFERENSI}

A., Irwan \& Novita Sri Aulia. (2016). Buku Kerja Praktek Mahasiswa (BKPM). Ekonomi Teknik. Payakumbuh: Politeknik Pertanian Negeri Payakumbuh. 


\section{I.UMIBUNG}

Khomsan, A. (2007). Sehat dengan Makanan Berkhasiat. Jakarta: Penerbit Buku Kompas.

Malasari. (2005). Sifat Fisik dan Organoleptik Nugget Ayam dengan Penambahan Wortel (Daucus carota L.). [Skripsi]. Bogor: Institut Pertanian Bogor.

Manalu, H. (2007). Analisis Finansial Usaha Tani Wortel. Medan : Universitas Sumatera Utara.

Utama, I. (2001). Paska Panen Segar Hortikultura. Denpasar: Universitas Udayana. 